\title{
ASSET MANAGEMENT BASED ON MANAGEMENT INFORMATION SYSTEM AND ACCOUNTING OF STATE PROPERTY (MANAGEMENT INFORMATION SYSTEMS AND ACCOUNTING FOR STATE PROPERTY) IN THE PUBLIC SERVICE AGENCY (BLU) UNIVERSITAS SEBELAS MARET SURAKARTA
}

\author{
Lelya Fetri Apriliana, Palikhatun, Payamta \\ Master Program of Accounting, Faculty of Economics and Business, \\ Universitas Sebelas Maret, Indonesia
}

\begin{abstract}
This research was conducted with the aim (1) To determine the implementation of Management Information Systems and Accounting for State Property (SIMAKBMN) in asset management within the Public Service Agency (BLU) of Universitas Sebelas Maret Surakarta; (2) To find out the advantages of implementing SIMAKBMN in asset management in the Universitas Sebelas MaretSurakarta; (3) To find out the problems in the implementation of SIMAK-BMN in asset management within the Universitas Sebelas MaretSurakarta; (4) To find out the solution to the problems in the implementation of SIMAK-BMN in asset management within the Universitas Sebelas Maret Surakarta. This research is a qualitative descriptive study. The source of the data came from interviews with 13 informants and related documents. The techniques of collecting data were by interview, observation, and documentation. The sampling technique in the study was purposive sampling. The research subjects in this study were officials and staff related to the management of BMN in Universitas Sebelas Maretwhich were represented by 13 people. Data analysis started from the stage of data collection, data reduction, data display, and conclusion. The results of the study showed that the actual rules regarding BMN Management have not been fully understood by stakeholders in the Universitas Sebelas Maret, this has the effect: the implementation of BMN management is not fully in accordance with applicable regulations; controlling the management of BMN is still weak, so it needs improvement to provide a good understanding of BMN management; currently the stakeholders of BMN management focus more on procurement, while the other management scope is still being ruled out.
\end{abstract}

Keywords : Asset Management, SIMAK-BMN

\section{Introduction}

In an organization, either it is owned by individuals/private or an organization that is owned by the public/government, they definitely have assets that must be managed. Management of these assets must be managed in an effective and efficient way to produce optimal asset performance. To manage the assets and wealth of the country, Indonesia utilizes the development of Information
Technology which will provide more facility in various management activities, starting from filing, calculation, and even the control and supervision of related assets. The administrative development through IT is a manifestation of manual to computerized administrative changes that is expected to minimize human error due to manual process. Asset management (AM) includes the proportion of the balance of costs, opportunities, and risks to be charged on the 
performance to be given by the asset itself, so that later it can fulfill the objectives of its owner (Love et al., 2014).

Many documentationsare needed for effective asset maintenance and operation (Teicholz, 2013). The information system helps the documentation process, especially for complex institutions. In government finance, the history of asset applications began with the application called SAAT (Fixed Asset Accounting System) (Cornelius, 2013). This is a financial application that helped the country in inventorying State Property throughout Indonesia. The application was used around 2003-2004 (Cornelius, 2013). After the application was run, it turned out that it did not give maximum results. Then itwas developed into the latest application called SABMN (State Property Accounting System).

SABMN was used around 2005 until mid-2008 (Cornelius, 2013). SABMN continued to experience improvements until the SIMAK-BMN application (Management Information Systems and Accounting for State Property) existed at the end of 2008 to the present.

Public Service Agency (BLU) is anagency that is expected to be a management change in public sector finance. Universitas Sebelas Maret (UNS) Surakarta, based on Minister of Finance Decree No.52/KMK.05/2009 on February 27, 2009, was established as a State University which applies the Financial Management Pattern of Public Service Agencies (PPK-BLU). Until now, UNS is still developing at least 3 types of accounting systems which are sub-systems of the BLU UNS accounting system, namely the financial accounting system, cost accounting system, and fixed asset accounting system. SIMAK BMN is the development of the State Property Accounting System (SABMN) which is used as a control tool for those who are in duties and responsibilities in the related agencies in the equipment/household so that it can match with the Unit Property Accounting Structure.

All of the fixed assets which contributed for the largest number in the total number of accounts on the 2014, 2015 and 2016 UNS BLU balance sheet, give encouragement to the authors to conduct research related to governance, administration of fixed assets and use of SIMAK BMN in the UNS environment, resulting in reporting BMN which contributes to the accuracy of the data in the preparation of BLU financial reports to realize agency accountability in which the implication is to minimize unhealthy practices in the flexibility of managing public funds in BLU UNS institutions so that good governance is expected to be the ultimate goal of public sector organizations.

\section{Theoritical Review}

\subsection{Management Information Systems and} Accounting for State Property
(SIMAK-BMN) According to the Minister of Finance Regulation No. 171 of 2007 concerning Central Government Accounting Systems:

"Management Information Systems and Accounting for State Property, hereinafter abbreviated as SIMAK$\mathrm{BMN}$, is a subsystem of SAI which is a series of interconnected procedures to process source documents in order to produce information for balance sheet transfers and BMN reports and managerial reports as well as other managerial report in accordance with applicable regulations."

According to the Minister of Finance Regulation Number 171 of 2007 concerning the Central Government Accounting System, State Property (BMN) covers all goods purchased or obtained at the expense of the State Budget or derived from other legitimate acquisitions. These other legitimate acquisitions include: 
a. Goods obtained from grants/donations or similar;

b. Goods obtained as implementation and agreements/contracts;

c. Goods obtained under the provisions of the law; or

d. Goods obtained based on court decisions that have obtained permanent legal provisions.

\subsection{Public Service Agency}

According to Government Regulation Number 23 of 2005 concerning Financial Management of Public Service Agency, it is stated about the definition of Public Service Agency (BLU). The definitions are as follows:

"Public Service Agency, hereinafter referred to as BLU, is an institution within the Government that is formed to provide services to the community in the form of goods and/or services sold without prioritizing profit seeking and in carrying out its activities based on the principles of efficiency and productivity."

The existence of a government agency with the status of a Public Service Agency is expected to be able to help the government's objectives in improving services provided to the public or the wider community. This is done in the context of fulfilling the general welfare and educating the nation's life as stated in the opening of the 1945 Constitution.

The fulfillment of the objectives of the country is through providing flexibility in the financial management of relevant institutions with BLU status based on economic principles and sound business practices. The financial management is included in the procurement of goods and services. Inventory items which are under the power of the BLU agency can be transferred to other parties or even deleted based on economic considerations.

\section{RESEARCH METHODOLOGY}

This research is a qualitative research. According to Sugiyono (2013) qualitative research brings an uncertain situation, meaning that the problems brought about in qualitative research are only temporary. This is because changes and developments are still possible when researchers have gone directly to the field to conduct the research. Unlike quantitative research, qualitative research does not focus on testing a hypothesis but on trying to answer research questions. Paradigm used in this study is the paradigm of the paradigm. This paradigm views social science as a systematic analysis of socially meaningful action through direct and detailed observation of the social behavior in question creating and maintaining or managing their social world (Hidayat, 2003).

This study took place in the Public Service Agency of UniversitasSebelasMaret (UNS) in Jalan Ir. Sutami No. 36 AKentingan Surakarta. The choice of location of this research was based on the main consideration that BLU UNS is one of the government agencies that is given authority in managing government assets through assistant application on government agency, which is SIMAK BMN.

Data collection techniques used in the research (Sugiyono, 2013: 62) were in the form of observation, interviews, and documentation. Documents used by researchers related to asset management with SIMAK-BMN at the UNS BLU include:

a. Report of the 2016 UNS BLU State Property

b. 2016 UNS BLU Financial Report

c. ISO Quality Procedure for BMN BLU UNS

d. BLU UNS Accounting Policy

The activities in analyzing qualitative research data were done continuously and interactively. The activities range were from data reduction, data presentation, and conclusions as expressed by Miles and 
International Journal of Economics, Business and Accounting Research (IJEBAR)

Peer Reviewed - International Journal

Vol-3, Issue-1, 2019 (IJEBAR)

ISSN: 2614-1280

http://www.jurnal.stie-aas/ijebar

Huberman (1992: 16-21) in Sugiyono (2013) which they called it as the Interactive Model of Analysis.

\section{RESEARCH FINDINGS}

In this study, data collection was conducted by observation, documentation and interviews with several informants, most of whom were actors and policy makers related to State Property in the BLU UNS. Based on the results of data reduction from 12 questions submitted by researchers, 32 indicators were found which were the indicators or answers that most often appeared in the interviews conducted.

After the researchers did the data reduction process in which the researchers summarized the main things, then the researcher presented the data reduction in the form of a brief chart image which represent the findings. It is usued to make it easier for users and readers to understand the research findings. The following are the results of the reduction depicted in the chart:
The Implementation of SIMAKBMN

- After 2008

- The replacement of SABMN

- Guided by PP dan SOP

- There are24 work unit assistants

- Filing based on SP2P

- Extra and intra items

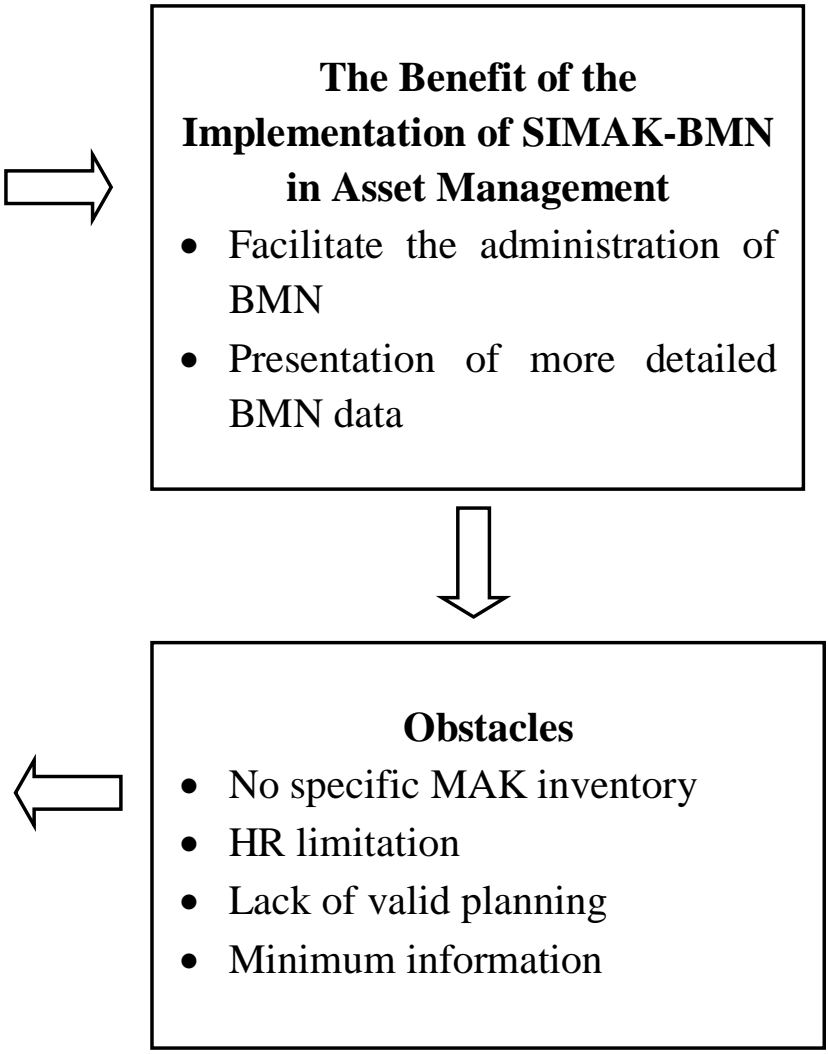

Figure 1. Data Chart Gathered From Finding

\subsection{The Scope of Management of State Property}

In this case, UNS is under the Ministry of Research, Technology and Higher Education (Kemristekdikti). The scope of asset management is based on Government Regulation No. 27 of 2014.
Based on the Regulation No. 27 of 2014 concerning Management of BMN stated that BMN management is done based on the following principles, which are: functional, legal certainty, transparency, efficiency, accountability, and certainty of value. According to this Government Regulation, 
Vol-3, Issue-1, 2019 (IJEBAR)

ISSN: 2614-1280

http://www.jurnal.stie-aas/ijebar

the scope of management of State Property consists of the following activities, including:

a. Needs and budgeting planning;

b. Procurement;

c. Use;

d. Utilization;

e. Security and maintenance;

f. Assessment;

g. Transfers;

h. Extermination;

i. Removal;

j. Administration;

k. Coaching, supervision and control.

\subsection{Asset Management Based On Simak- BMN In BLU Of UNS Surakarta Environment}

The procedure for asset management in the BLU of UNS generally refers to the Republic of Indonesia Government Regulation Number 27 of 2014 concerning Management of State/Regional Property. Reporting of State Property is organized according to the estimated balance sheet consisting of current assets, fixed assets and other assets. Current assets are tangible inventories, tangible fixed assets of land, equipment and machinery, buildings, irrigation roads and networks, other fixed assets and construction under construction. Other assets consist of intangible assets, and fixed assets that are terminated from the operational use of the government.

The following is the legal basis used as a guideline for filing assets to SIMAK BMN within the BLU of UNS:

a. Law no. 17 of 2003 concerning State Finance

b. Law no. 1 of 2004 concerning State Treasury

c. Republic of Indonesia Government Regulation Number 6 of 2006 concerning Management of State/Regional Property

d. Regulation of the Minister of Finance Number 102/PMK.05/2009 concerning Procedures for Reconciliation of State
Property for Preparation of Central Government Financial Statements

e. Regulation of the Director General of State Assets Number: PER-07/KN/2009 concerning Procedures for Implementing Reconciliation of Data on State Property in the Context of Compilation of Statements of State Property and Central Government Financial Reports.

The implementation of goods management accounting is facilitated by the use of SIMAK-BMN application. This software allows simplification of processes that are usually done manually to be systemized so as to reduce the level of human error. BLU of UNS has 24 work units of assistants in BMN management.

\section{Needs and Budgeting Planning}

The process of preparing a budget needs planning document starts from identifying the required $\mathrm{t}+1$ program activity plan. Then the Head of Section will verify the feasibility of the activity program, including per type of Activity Budget (MAK), both goods expenditure and capital expenditure that will be a priority. Then proceed with the preparation of the Term of Reference (TOR) and Cost Budget Plan (RAB) activities to be carried out $t+1$ by each Head of Subdivisions. Then the TOR and $\mathrm{RAB}$ are re-verified by the Head of Section before all submissions from the SubSection are finally compiled into one and are proposed to the Head of the Bureau to be ratified.

After being approved by the Head of the Finance and General Bureau, TOR and RAB were submitted to the Planning Section and then were analyzed by the Planning and Development Team (Renbang). By this team, each work unit budget proposal will be through analysis and revision if it is inappropriate.

After the analysis and revision process by the R \& D team is completed, then TOR and $\mathrm{RAB}$ were uploaded to the Planning 
System (SiRen). The upload results on this system will later become the basis for each activity budget expenditure. From this explanation, it can be concluded that budgeting needs in the BLU of UNS is a participatory budgeting, where subordinates/budget implementers are included or involved in the period budgeting process.

\section{Procurement}

Procurement in the BLU of UNS contains several procurement items, including:
a. Procurement of goods
b. Procurement of construction work
c. Procurement of consulting services, and
d. Procurement of other services.

\section{Removal}

The removal of State Property includes the removal of a list of user/power users' items as well as the removal from the list of State Property. The removal of BMN at the BLU of UNS includes:
a. BMN removal of inventory
b. BMN removal by means of destruction
c. BMN removal of buildings
d. BMN removal motor vehicles
e. BMN removal of loss

The initial process of receiving a request for $\mathrm{BMN}$ removal by the $\mathrm{BMN}$ Section is verified by the Head of the Subdivision of Inventory and Removal. Then the removal committee checks the BMN which will be abolished and makes the news of the research and BMN assessment to be written off. Then the inventory and removal staff prepare the complete deletion file which includes: SK Committee; BMN photos; statement not to interfere with activities; statement of responsibility for limit value; print out conditions change transactions, print out transaction termination from use; print the BMN List that was stopped. After that, the staff made a recommendation for BMN removal to the State Wealth and Auction Service Office (KPKNL).
Furthermore, the request for a decree to the Minister of Research Technology and Higher Education, after the decree is issued, it can be used as the basis for the SIMAK-BMN operator to reclassify the recording of assets in the application for the abolition.

\subsection{Problems Related To Asset Management And Its Filing Into Simak-BMN In Blu Of UNS Environment}

\section{Needs and Budgeting Planning}

At the planning stage, it has not yet fully reviewed and validated the submitted proposals (still limited to compilation). In addition, many of the work units are still conducting their own procurement, meaning that procurement is not centralized in the procurement department.

In addition, all stakeholders in the UNS have not yet understood the existence of MAK inventory which was just launched in 2018.

\section{The BMN}

There were difficulties when submitting the Determination of Use Status (PSP) especially on BMN in the form of building. This was due to the requirement to apply for the PSP building was the existence of IMB, which in fact the UNS buildings was built first before the IMB was made.

\section{The Utilization of BMN}

All of the BMN utilization within UNS has not submitted a permission to the Property Manager. In Government Regulation No. 742012 concerning Amendment to PMK no. 232005 concerning Financial Management of BLU, Article 22 paragraph 4 states that "Utilization of fixed assets for activities not related or not in order to support the implementation of BLU duties and functions must be approved by the competent authority in accordance with the provisions of legislation". 
According the sentence above, in accordance with the provisions of the legislation, we think that this is in line with the PMK number 78 of 2014 concerning Procedures for Implementing BMN Utilization. And if our thoughts are correct, then the use of assets that do not support the tasks and functions, must be permitted to the Property Manager. Whereas what happened was that there had been no stipulation from the University leadership regarding the limits on the use related to the tax and which were not related to the problem.

In addition, other problems are related to the procedures for implementing $\mathrm{BMN}$ utilization (specifically BMN leases) and the amount of the lease value not in accordance with PMK 57 of 2016 concerning Procedures for Implementing BMN Leases. This causes:

a. Different rental procedures in each work unit

(Faculty/PPS/Institution/Technical

Implementation Unit) that are within the scope of the UNS;

b. Determination of basic values that have not been same, so that with the same rental object, it can produce a different amount of rent.

\section{Security and Maintenance of BMN}

Lack of attention in administering postprocurement BMNs, for example: the progress in achieving BMN data input into Room Goods List (DBR): BMNs are not given inventory numbers; List of Room Items (DBR) is not updated; BMN is not included in the DBR. In addition, other problems were that the person in charge of the work unit assistant had not all proposed the BMN maintenance budget (Building Building and Machine Tools) in the scope of their responsibility.

\section{Transfer/Removal of BMN}

The problem with the transfer/removal of $\mathrm{BMN}$ is that it is still being found that the case of property that have been auctioned is still being used again. Besides that, the SIMAK BMN data on the work unit assistants is not fully in accordance with the reality of BMN in the field.

\section{Administration}

Problems related to Administration of Official Residence include the following:

a. Allotment is not in accordance with the rules (example: official residence is used for student secretariat, official residence is used for canteen);

b. Residents who occupy are not in accordance with the provisions (example: occupied by retirees/children from retirees who used to occupy);

c. In issuing SIP (Residential Permit), provisions must be mentioned.

\section{Solutions for the Obstacles of SIMAK- BMN Implementation in Asset Management in BLU of UNS Environment}

It is necessary to review the suitability of MAK use for procurement to be paid. Besides that, it should be conveyed to SIMAK-BMN operators/inventory related to the procurement that has been paid, so that synchronization of records will be made into the application. In addition, with the derivation of the organizational structure of the Authorized User in this case from the University level to the Faculty level, it is also expected to be able to provide better coordination. It is in line with the study cunducted by Akmal (2006) which prove that the coordination between departments enhance to speedy all departments' goal.

The Property Manager can conduct an investigation if there are indications of irregularitiesfrom the results of monitoring, in this case the one who has the right to conduct an investigation is the Head of the Finance and General Bureau who oversees the BMN section. Investigation was conducted to collect evidence, which with the evidence makes the problem for settlement/controlclearer. In addition, 
coordinating with relevant agencies such as the Ministry of Research, Technology and Higher Education, State Assets and Auction Service Office, or other parties needs to be done to provide solutions to related problems.

Based on the results of the investigation, the Property Manager can ask the government internal control apparatus (SPI) to conduct an audit. This audit is done if there is an indication of state losses and or irregularities in BMN management.

\section{CONCLUSION}

Management of BMN at BLU of UNS in accordance with PP No. 27 of 2014 concerning Management of BMN are as follows: needs planning and budgeting, procurement, use, utilization, security and maintenance, assessment, transfer, destruction, deletion, administration, guidance, supervision and control. In accordance with Law No. 1 of 2004 concerning State Treasury that the treasury itself includes management and accountability. In managing assets, it cannot be separated from the process of accountability. The accountability is through a balance sheet consisting of current assets, fixed assets and other assets. The balance sheet output comes from the BMN Accounting Information System. According to the research on asset management at BLU of UNS, it can be concluded that in fact the rules regarding BMN Management have not been fully understood by stakeholders in Universitas Sebelas Maret, this has the following consequences:

a. The implementation of BMN management is not fully in line with applicable regulations;

b. The controlling of the management of BMN is still weak, so it needs improvement to provide a good understanding of BMN management;

c. In addition, it can also be concluded that the stakeholders of BMN management focus on procurement more, while the other management areas are still being ruled out.

For the sake of stakeholder understanding, a socialization of BLU asset management is should be conducted regularly. It is intended to keep the data or information related to assets up to date. Next, it suggested for Universitas Sebelas Maret to add more professional resources to handle controlling process for improving a good understanding of BMN management. The last, all aspect on BMN management should be managed by devided the task evenly as they are indespensable.

\section{BIBLIOGRAPHY}

Andira, Ayu. 2012. Analisis Implementasi Prinsip-Prinsip Good Corporate Governance (GCG) dan Hubungannya Terhadap Kinerja PT. United Tractors Tbk. Cabang Makassar. Skripsi pada Fakultas Ekonomi Universitas Hasanuddin: tidak diterbitkan

Akmal. 2006. Koordinasi antar instansi terkait dalam pelaksanaan pembangunan daerah. Jurnal demokrasi. Vol 5(1),1-10.

Azwar Saifudin. 2004. Metode Penelitian. Yogyakarta: Pustaka Pelajar

Dedy N. Hidayat. 2003. Paradigma dan Metodologi Penelitian Sosial Empirik Klasik, Jakarta : Departemen Ilmu Komunikasi FISIP Universitas Indonesia.

Governmental Accounting Standard Board (GASB). 1999. "Concepts Statement No.1: Objective of Financial Reporting" in Governmental Accounting Standards Series 
International Journal of Economics, Business and Accounting Research (IJEBAR)

Peer Reviewed - International Journal

Vol-3, Issue-1, 2019 (IJEBAR)

ISSN: 2614-1280

http://www.jurnal.stie-aas/ijebar

Statement No. 34: Basic Financial Statement and Management's Discussion and Analysis for State and Local Governments. Norwalk

Hanis, Muhammad Hasbi et al. 2011. The Application of Public Asset Management in Indonesian Local Government. Journal of Corporate Real Estate. Vol. 13 Iss 1 pp. 36 - 47

Keputusan Menteri Keuangan Nomor: 52/KMK. 05/2009 Tentang Penetapan Universitas Sebelas Maret Surakarta Pada Departemen Pendidikan Nasional Sebagai Instansi Pemerintah Yang Menerapkan Pengelolaan Keuangan Badan Layanan Umum. 2009

Keputusan Rektor Universitas Sebelas Maret Surakarta No. 205A/H27/KU/2011 Tentang Kebijakan Akuntansi Badan Layanan Umum Universitas Sebelas Maret Surakarta. 2011

Komite Standar Akuntansi Pemerintah. 2014. Buletin Teknis Standar Akuntansi Pemerintah Nomor 15 Tentang Akuntansi Aset Tetap Berbasis Akrual. Jakarta

Kornelius, Nicko. 2013. Telaah Kritis Penerapan Sistem Informasi Manajemen Danakuntansi Barang Milik Negara (Simak-BMN) TNI Tahun 2010-2012. S2 Magister Sains, Universitas Gadjah Mada

Jim, D. 2007. What is Asset Management and Where Do You Start?. American Water Works Association Journal. Vol. 99 No. 10, p. 26

Love, Peter E.D. et al. 2014. A Systems Information Model For Managing Electrical, Control, and Instrumentation Assets. Built Environment Project and Asset
Management. Vol. 5 No. 3, 2015. pp. 278-289

Mahsun, Mohamad. 2012. Pengukuran Kinerja Sektor Publik. BPFEYogyakarta. Yogyakarta

Mardalis. 2007. Metode Penelitian-Suatu Pendekatan Proposal. Jakarta: Bumi Aksara

Meirinitawati. 2006. Penerapan Sistem Informasi dan Manajemen Akuntansi Barang Milik Negara (Simak BMN) Di Kantor Pusat Humaniora, Kebijakan Kesehatan dan Pemberdayaan Masyarakat Surabaya. S1 Ilmu Administrasi Negara, FIS, UNESA

Miles \& Huberman. 1992. Analisis Data Kualitatif. (Terjemahan: Tjetjep Rohendi Rohidi). Jakarta: Universitas Indonesia Press

Peraturan Rektor Universitas Sebelas Maret Nomor 269 tentang Kebijakan Akuntansi Badan Layanan Umum Universitas Sebelas Maret. 2016

Podrug, N. 2011. The StrategicRrole Of Managerial Stewardship Behaviour For Achieving Corporate Citizenship. Ekonomski Pregled. Vol. 62 (7-8)

Rahayu et al. 2014. Penerapan Sistem Informasi Akuntansi Barang Milik Negara Pada Pengadilan Tinggi Agama Manado

Republik Indonesia. 2004. Undang-Undang Nomor 1 Tahun 2004 Tentang Perbendaharaan Negara

2005. Pernyataan Standar Akuntansi Pemerintahan 
Nomor 5 Tentang Akuntansi Persediaan

2006. Peraturan Menteri

Keuangan Nomor 07 Tahun 2006

Tentang Persyaratan Administratif Dalam Rangka Pengusulan dan Penetapan Satuan Kerja Instansi Pemerintah Untuk Menerapkan Pola Pengelolaan Keuangan Badan Layanan Umum

2006. Peraturan Pemerintah Nomor 6 Tahun 2006 Tentang Pengelolaan Barang Milik Negara/Daerah

2008. Peraturan Menteri

Keuangan Nomor 76/PMK.05/2008

Tentang Pedoman Akuntansi dan Pelaporan Keuangan Badan Layanan Umum

2012. Peraturan Pemerintah Nomor 74 Tahun 2012 Tentang Perubahan Atas Peraturan Pemerintah Nomor 23 Tahun 2005 Tentang Pengelolaan Keuangan Badan Layanan Umum 2013. Peraturan Menteri Keuangan Nomor 213/PMK.05/2013 Tentang Sistem Akuntansi dan Pelaporan Keuangan Pemerintah Pusat.

2014. Peraturan Pemerintah Nomor 27 Tahun 2014 Tentang Pengelolaan Barang Milik Negara/Daerah

2015. Peraturan Presiden Republik Indonesia Nomor 4 Tahun 2015 Tentang Perubahan Keempat Atas Peraturan Presiden Nomor 54 Tahun 2010 Tentang Pengadaan Barang/Jasa Pemerintah
2016. Peraturan Menteri

Keuangan Republik Indonesia Nomor 220/PMK.05/ 2016 Tentang Sistem Akuntansi Dan Pelaporan Keuangan Badan Layanan Umum

Sub Bagian Akuntansi dan Pelaporan Bagian Keuangan UNS. 2015. Laporan Keuangan BLU UNS Audited Periode 31 Desember 2015

Sub Bagian Inventaris dan Penghapusan Bagian Barang Milik Negara UNS. 2015. Laporan Barang Milik Negara Audited Periode 31 Desember 2015

Sugiyono. 2013. Metode Penelitian Pendidikan (Pendekatan Kuantitatif, Kualitatif, dan R\&D). Bandung: Alfabeta

Teicholz, P. 2013. BIM for Facility Managers. Wiley and Sons. Hoboken. NJ.

Thorton D. Deborah. 2009. Stewardship in Government Spending: Accountability, Transparency, Earmarks, and Competition. Policy Study No. 09-1. Public Interest Institute

Waluyo. 2007. Manajemen Publlik (konsep, aplikasi dan implementasinya dalam pelaksanaan Otonomi Daerah). Bandung: Mandar Maju

Wilkinson, Joseph W., Cerullo, Michael, Michael J, Raval, Vasant, Wongon-Wing, Barnard. 2000. Accounting Information System: Essential Concept and Application. 3rd Edi. New York, John Wiley and Sons 